\title{
Skin cancer and vitamin D: an update
}

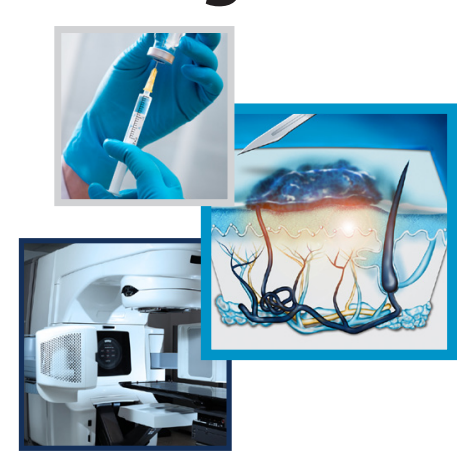

\author{
Candy Wyatt ${ }^{1,2}$, Rachel E Neale ${ }^{3}$ \& Robyn M Lucas*,1,2
}

\section{Practice points}

\section{Skin cancer incidence, mortality, burden \& cost}

- Accurate incidence rates are hard to capture for the keratinocyte cancers, squamous cell carcinoma and basal cell carcinoma.

- Fatality rates for keratinocyte skin cancers are low, but approximately 55,000 deaths result from melanoma each year.

- Skin cancers cause a significant health burden and cost to healthcare systems.

UV radiation \& skin cancer

- Exposure to UV-A radiation causes free radical production, resulting in oxidative damage.

- Exposure to UV-B radiation induces DNA damage; recent genetic studies confirm many UV 'signature mutations' in skin cancers, including both driver and bystander mutations.

- UV-induced immunosuppression results from irradiation in both UV-A and UV-B wavelengths and is an important factor in skin cancer development.

Vitamin D, skin cancer risk \& prognosis

- Exposure to the sun causes both skin cancer and vitamin D production.

- Cutaneous production of vitamin D is initiated by exposure to UV-B radiation.

- Serum concentrations of 25 -hydroxyvitamin D (25(OH)D) of $50 \mathrm{nmol} / /$ or higher are classed as sufficient.

- Studies exploring the relationship between skin cancer risk and vitamin D show mixed results.

- Results from human studies are consistent in reporting that low levels of $25(\mathrm{OH}) \mathrm{D}$ are associated with thicker cutaneous malignant melanomas or a poorer prognosis.

\section{What to tell skin cancer patients}

- Caution should be taken to avoid harmful levels of sun exposure.

- It is important to maintain vitamin D levels above $50 \mathrm{nmol} / \mathrm{l}$.

- Patients at high risk of skin cancer should routinely apply sunscreen to the face, hands and arms. Areas less frequently exposed to UVR may be exposed for short periods (e.g., $10 \mathrm{~min}$ ) in the middle of the day when the UV-B levels are highest. 


\section{KEYWORDS}

- basal cell carcinoma

- keratinocyte cancer

- melanoma - squamous cell

carcinoma - sun exposure

- vitamin D

SUMMARY Exposure of the skin to solar ultraviolet (UV) radiation has both risks and benefits for human health. Absorption of UV-B radiation by DNA results in mutations that underlie the development of skin cancers, as is apparent from genetic studies showing high occurrence of UV signature mutations within these tumors. UV-B radiation is also absorbed by 7-dehydrocholesterol to initiate vitamin $D$ synthesis. In experimental studies vitamin $D$ metabolites enhance apoptosis of malignant cells, inhibit angiogenesis and proliferation and increase differentiation, potentially reducing skin cancer development and improving prognosis after diagnosis. There are some supporting human data. We review the links between sun exposure, vitamin D and skin cancers.

Skin cancer incidence, mortality, burden

\& cost

Cutaneous malignant melanoma (CMM) and the keratinocyte cancers (KCs), predominantly basal cell carcinoma (BCC) and squamous cell carcinoma (SCC), cause a significant public health burden. In 2012 there were approximately 230,000 new cases of CMM worldwide, with over $80 \%$ of these occurring in more developed regions of the world [1]. Although the 5-year survival is high, up to $90 \%$ in some countries such as Australia, there are approximately 55,000 deaths from CMM each year. The incidence of CMM has doubled each decade since the 1960s and this trend is likely to continue for at least the next two decades [2]. There are indications that incidence rates are plateauing or decreasing in younger age groups in some countries, possibly because younger cohorts have been exposed to public health messages from an early age [2]. Of note, however, a recent publication suggests that, an apparent decrease or stabilization of incidence is no longer apparent when the population denominator is adjusted to remove those at low risk of CMM, such as dark-skinned immigrants [3].

KCs have a very low case fatality rate, but a very substantial economic impact [4] as they are the most commonly occurring cancers in fairskinned populations. However it is very difficult to capture accurate incidence rates and analyze geographic differences or temporal trends for a number of reasons. First, a tissue diagnosis may not be obtained for lesions that are treated destructively. Thus differences in management approaches between countries or changes over time could substantially affect international comparisons and trends. Second, there are few cancer registries that require mandatory reporting of KCs and there are very few high quality population-based studies. Finally, many people are diagnosed with multiple KCs either contemporaneously or sequentially, so calculation of person-based incidence rates results in a considerable underestimation of the $\mathrm{KC}$ burden. Despite these challenges, there is strong evidence that $\mathrm{KC}$ incidence has increased markedly in the last several decades. A recent analysis has shown that after adjustment for age, sex and the levels of ambient UV radiation, the average annual increases in SCC and BCC incidence were 4 and $1 \%$, respectively [5].

\section{UV radiation \& skin cancer}

There is considerable evidence showing that exposure to the sun causes skin cancer, including from observations of geographical variation in incidence, a higher risk in people with fair skin, an increased risk in people with markers of actinic damage such as actinic keratoses and the presence within tumors of 'UV-signature' genetic mutations (cytosine to tyrosine transitions at cyclobutane pyrimidine dimers).

Country of residence is an important determinant of the absolute risk of a CMM occurring in a fair-skinned person [6]. There is a clear latitude gradient of increasing incidence with decreasing latitude [7-10]. Within Australia the potential influence of latitude is clearly demonstrated in the decreasing incidence rates from north to south $[7,11]$. This is not the case in Western Europe, however, where the European national cancer registries report that the highest incidence rates are found in the Scandinavian countries [7,12]. This is probably because European populations at lower latitude have darker skin types, and also because people living in high latitude locations commonly take low latitude sunny holidays [13]. The latter argument is supported by the socioeconomic differences in CMM incidence that have been reported in Scandinavia [14].

Despite the difficulties in ascertaining the true incidence of $\mathrm{KCs}$, there is a strong association between $\mathrm{KC}$ incidence and intensity of ambient ultraviolet radiation (UVR) [15]. In a recent quantitative review restricting the analysis to fair-skinned populations only, intensity of 
ambient UVR accounted for almost $40 \%$ of the variability in incidence of SCC and BCC (with age, sex and calendar year additional important factors) [5].

Evidence for an important role for exposure to UVR in skin cancer risk also arises from its predilection for fair-skinned peoples [16-18]. For example, the highest incidence is in Australia (>1000 per 100,000 population) and the lowest in Africa $(<1$ per 100,000) despite generally higher levels of ambient UVR in the latter. In recent meta-analyses, fair skin phenotype or sun sensitive phototype was a key risk factor for CMM. The difference in incidence of skin cancers (including CMM and $\mathrm{KC}$ ) between fair- and dark-skinned populations living in the same geographic location clearly illustrates the importance of skin type [19].

Recent meta-analyses have also confirmed that greater numbers of naevi and atypical naevi, and the presence of actinic damage and $\mathrm{KC}$ are strong risk factors for CMM [20-22]. In a recent report, there was a threefold increase in the risk of developing CMM after either SCC or BCC, even after adjustment for skin phototype [23].

Genetic studies show an increased risk of CMM in association with polymorphisms in genes determining skin phototype, for example $M C 1 R$ [24]. Within CMM, characteristic UV-induced cytosine to thymine $(\mathrm{C}>\mathrm{T})$ mutations in tumor control pathways (e.g., $R A C 1$, STK19 and PPP6C genes) are found [25]. Both $\mathrm{BCC}$ and SCC show 'UV signature' mutations ( $\mathrm{C}>\mathrm{T}$ at cyclobutane pyrimidine dimers) in tumor suppressor genes, particularly the TP53 gene [26-28]. For both CMM and KC, tumors from sun-exposed sites have the greatest mutation loads, and most of the mutations bear the 'UV signature' [28-31].

Despite these clear associations between exposure to the sun and all three tumor types, the patterns and timing of sun exposure that give rise to them differ. SCC appears to be most strongly linked to total lifetime sun exposure [32], but intermittent high dose exposure, as exemplified by a history of sunburn, appears to play an important role in development of BCC and melanoma [33]. Additionally, childhood sun exposure may be particularly important for CMM [34] and possibly BCC [35]. For melanoma, and possibly BCC, there may be added complexity, with the association with pattern and timing of sun exposure differing depending on the site of the tumor. CMMs occur on skin sites not commonly exposed to the sun, particularly in younger people and indoor workers, but have a predilection for sun-exposed sites in older populations. This finding has led to a 'divergent pathways' theory whereby melanomas of the head and neck are related to cumulative sun damage (consistent with their occurrence in older age groups), whereas CMMs of the trunk are associated with melanocyte proliferation due to skin phenotype, specific genetic mutations and intermittent sun exposure [36]. Similarly, chronic sun exposure may be more important for nodular BCC commonly found on the head and neck, and intermittent sun exposure more important for BCCs on the trunk [37].

\section{An introduction to vitamin D}

The vitamin D precursor, 7-DHC, is present in the plasma membrane of epidermal keratinocytes. Shorter wavelength UV-B radiation breaks open the $\mathrm{B}$ ring of the steroid to form previtamin $\mathrm{D}_{3}$, which subsequently undergoes thermal isomerization to form cholecalciferol, also called vitamin $\mathrm{D}_{3}$. There are dietary sources of both vitamin $\mathrm{D}_{3}$ and the form found in some fungi, vitamin $\mathrm{D}_{2}$, although few foods are naturally rich in these nutrients. The active form of vitamin $\mathrm{D}, 1,25$ dihydroxyvitamin $\mathrm{D}(1,25(\mathrm{OH}) \mathrm{D})$, is produced following two separate hydroxylation reactions. The first occurs in the liver and produces the intermediary, 25-hydroxyvita$\min \mathrm{D}(25(\mathrm{OH}) \mathrm{D})$ that is measured in serum to determine vitamin $\mathrm{D}$ status. The second occurs primarily in the kidneys, although other tissues express the enzymes needed to carry out this reaction, so that $1,25(\mathrm{OH}) \mathrm{D}$ can be produced within cells, including those of the skin [38].

Production of vitamin $\mathrm{D}_{3}$ in the skin is influenced by factors that affect ambient levels of UV-B radiation: location (latitude, longitude and altitude), time of year and time of day and cloud cover [39]. At the individual-level, there is a nonlinear dose response between UV-B irradiation and vitamin $\mathrm{D}$ production that depends on the starting level of $25(\mathrm{OH}) \mathrm{D}[40,41]$. Other factors that moderate the amount of vitamin $\mathrm{D}_{3}$ produced following irradiation of the skin include the orientation to the sun (i.e., horizontal vs vertical) [42], and the amount of the body surface that is exposed [43]. Use of sunscreen at recommended levels $\left(2 \mathrm{mg} / \mathrm{cm}^{2}\right)$ decreases the effectiveness of vitamin D production [44], but epidemiological studies suggest that frequent sunscreen users do not have lower levels of $25(\mathrm{OH}) \mathrm{D}$ than 
infrequent users after taking account of the time spent outdoors [45-47]. The moderating effect of skin pigmentation (melanin density) is controversial, although most experimental studies using lamps with an output that is realistic for sun exposure at Earth's surface show that darker skin decreases the amount of vitamin $\mathrm{D}$ produced for any dose of UV-B radiation [40,42,48-53].

The actions of $1,25(\mathrm{OH}) \mathrm{D}$ are primarily mediated through ligation with a nuclear vitamin $\mathrm{D}$ receptor (VDR), resulting in genomic responses. In addition, there are membrane rapid response receptors that are distributed in most, if not all, human tissues [54]. Systemically produced $1,25(\mathrm{OH}) \mathrm{D}$ has a primary role in maintaining calcium homeostasis [55], and in recent years, vitamin $\mathrm{D}$ deficiency has been linked to an increased risk of a wide range of diseases [56,57]. Importantly, particularly for potential associations with skin cancer, the full vitamin D biosynthetic pathway can occur within the epidermis [38]. The 25-hydroxylase mRNA is not constitutively expressed but is induced by vitamin $\mathrm{D}_{3}$ and UV-B radiation [58]. Active $1,25(\mathrm{OH})_{2} \mathrm{D}$ can therefore be synthesized and act within the cell to have local effects. The VDR is expressed in melanocytes [59] and keratinocytes [60]. In vitro, within the epidermis, $1,25(\mathrm{OH}) \mathrm{D}$, acting through the VDR, reduces the proliferation of keratinocytes and melanocytes and promotes differentiation, including of keratinocytes as they migrate outward from the basal layer to form the upper layers of the epidermis [38,61,62]

\section{- Vitamin D \& skin cancer risk}

Identifying the role of vitamin D in the etiology of skin cancer in humans is extremely challenging, because exposure to the sun causes both vitamin $\mathrm{D}$ production and skin cancer. Much of the evidence arises from studies in vitro or in mouse models, with additional information from epidemiological and genetic studies in humans.

Recent studies in vitro, in mouse models, and in humans have explored the links between vitamin $\mathrm{D}$ metabolites and skin cancer development and progression. It is worth briefly examining the types of evidence arising from these different approaches.

In vitro, epidermal cells or tissue are typically bathed in vitamin $\mathrm{D}$ metabolites or analogues and this may be at physiological or pharmacological doses that might not be relevant to typical epidermal levels. In mouse models, 1,25(OH)
$\mathrm{D}$ or analogues are applied topically to explore the protective effect of higher local levels of $1,25(\mathrm{OH}) \mathrm{D}$, that are thought to arise from local, epidermal, synthesis. Genetic knockout mice provide evidence related to systemic as well as local vitamin $\mathrm{D}$ deficiency, but are typically highly abnormal across a range of characteristics. Genetic studies of tumor cells compared with normal skin cells provide evidence of specific abnormalities that may indicate a role for vitamin $\mathrm{D}$, such as within vitamin $\mathrm{D}$ pathway genes. In human studies, observational studies typically examine links between levels of $25(\mathrm{OH}) \mathrm{D}$ and skin cancer incidence or progression but it is difficult to tease out effects of vitamin D versus the effects of sun exposure, since the latter is a principal determinant of $25(\mathrm{OH}) \mathrm{D}$ levels. Candidate gene approaches and evidence in relation to dietary intake of vitamin $\mathrm{D}$ provide specific evidence of a vitamin $\mathrm{D}$ effect.

Pretreatment with high dose $1,25(\mathrm{OH}) \mathrm{D}$ decreased DNA damage and protected keratinocytes in vitro from UV-B-induced apoptotic cell death [63]. When $1,25(\mathrm{OH}) \mathrm{D}$ was topically applied in mice susceptible to UV-induced tumor development, the formation of cyclobutane pyrimidine dimers, apoptotic sunburn cells and the development of SCC following UV irradiation were reduced [64]. Some, but not all, melanoma cell lines are responsive to the antiproliferative effects of $1,25(\mathrm{OH}) \mathrm{D}[65,66]$, possibly through epigenetic pathways [67] and/or modulation of clusterin expression [68].

$V D R$ knockout mice develop skin tumors following UV irradiation but mice lacking the CYP27B1 gene (and thus unable to make $1,25(\mathrm{OH}) \mathrm{D})$ do not [69]. This suggests that the VDR itself functions as a tumor suppressor in the skin (possibly through the hedgehog signaling pathways and $\beta$-catenin [70] via regulation of the expression of long noncoding RNAs [71]), rather than this being a pathway that involves 1,25(OH)D [72]. Notably, BCC, SCC and CMM cells express the VDR [72].

\section{Melanoma in humans}

Recent studies have explored the links between vitamin D status and CMM risk, with conflicting results. In a case-control study nested within the Alpha Tocopherol Beta-Carotene Cancer Prevention Study, there was no association between $25(\mathrm{OH}) \mathrm{D}$ levels and development of CMM at a median of 8.9 years of follow-up [73]. However, two recent prospective studies, from Denmark [74] and Australia [75], showed that higher 25(OH)D levels 
at baseline were associated with higher incidence of CMM (and BCC) suggesting that $25(\mathrm{OH}) \mathrm{D}$ is a surrogate for sun exposure and that people with higher concentrations are at increased risk of skin cancer. Two recent meta-analyses, including these studies, support these findings, also showing an association of higher $25(\mathrm{OH}) \mathrm{D}$ concentrations with higher incidence of CMM [56,76].

In a recent meta-analysis, there was no evidence that vitamin $\mathrm{D}$ intake from food or supplements alters the risk of CMM, although there have been few studies and there was considerable heterogeneity [76]. Clinical trials may help to elucidate the effects of vitamin D intake on skin cancer risk, but there has been only one trial reported to date [77]. It found no overall effect of vitamin D and calcium supplementation on CMM risk, but among women with a history of $\mathrm{KC}$ there was a protective effect for melanoma.

In a recent meta-analysis of CMM risk in relation to polymorphisms in the $V D R$ there was a modest increase in risk of CMM in association with the Ff and ff genotypes of the FokI polymorphism (compared with the wild-type; summary relative risk [SRR]: 1.21 [95\% CI: 1.03-1.42] and 1.21 [95\% CI: 0.95-1.54], respectively). There was a decreased risk of $\mathrm{CMM}$ with the $\mathrm{Bb}$ and $\mathrm{BB}$ genotypes (vs wild-type) of the BsmI polymorphism (summary relative risk: 0.78 [95\% CI: 0.65-0.92] and 0.75 [95\% CI: 0.59-0.95], respectively) [78]. Similar findings are reported from a case-control study [79]. In a hospital-based case-control study there was a significant decrease in risk of CMM in association with the $\mathrm{Tt}$ genotype (compared with TT) of the TaqI polymorphism of the $V D R$ (adjusted OR [AOR]: 0.70; 95\% CI: 0.54-0.90). However, in another case-control study of 305 CMM cases and 370 healthy controls there was no association between CMM risk and single nucleotide polymorphisms (SNPs) within the $V D R$ or CYP27B1 (encoding the $1 \alpha$-hydroxylase enzyme that converts $25(\mathrm{OH}) \mathrm{D}$ to $1,25(\mathrm{OH}) \mathrm{D})$, CYP24A1 (encoding the 24-hydroxylase enzyme that breaks down $1,25(\mathrm{OH}) \mathrm{D}$ ) or $V D B P$ (encoding the vitamin $\mathrm{D}$ binding protein) [80].

\section{Keratinocyte cancers in humans}

The epidemiological evidence for a role of vitamin $\mathrm{D}$ in $\mathrm{KC}$ risk is similarly contradictory, but perhaps more heavily weighted toward a positive association between higher $25(\mathrm{OH}) \mathrm{D}$ levels and higher KC risk.

In a nested case-control study of older American men in the Osteoporotic Fractures in
Men Study, men in the highest quintile of $25(\mathrm{OH})$ $\mathrm{D}(\geq 75 \mathrm{nmol} / \mathrm{l})$ had a $46 \%$ lower odds of a history of KC (self-reported at 5 year follow-up) compared with the lowest quintile $(<40 \mathrm{nmol} / \mathrm{l}$; AOR: 0.54 , $0.31-0.96)$ [81]. There was no significant association for incident $\mathrm{KC}$, although the numbers of these were quite small $(n=100)$. Similarly, the median serum level of $25(\mathrm{OH}) \mathrm{D}$ was significantly higher in the control group compared with the patients with BCC (29.5 vs $24.2 \mathrm{ng} / \mathrm{ml}, \mathrm{p}=0.003)$ in another study, although here blood samples were collected 2 weeks postdiagnosis [82].

Most other studies show the opposite: an increased risk of $\mathrm{KC}$ in association with higher $25(\mathrm{OH}) \mathrm{D}$ levels. In a case-control study, women in the highest quartile of serum $25(\mathrm{OH}) \mathrm{D}$ concentration (compared with the lowest quartile) had an increased risk of BCC (AOR: 2.07; 95\% CI: $1.52-2.80$ ) and SCC (AOR: 3.77; 95\% CI: 1.70-8.36) [83]. Similarly in nested case-control studies from northern California [84], Denmark [74] and Australia [75], higher 25(OH)D levels were associated with increased risk of BCC. Interestingly, in the Australian study, there was a nonsignificant lower risk of SCC in association with $25(\mathrm{OH}) \mathrm{D}>75 \mathrm{nmol} / \mathrm{l} \mathrm{cf} . \leq 75 \mathrm{nmol} / \mathrm{l}[75]$. Recent meta-analyses including these studies show an association of higher $25(\mathrm{OH}) \mathrm{D}$ concentrations with higher incidence of $\mathrm{KC}[56,76]$ and no association between vitamin $\mathrm{D}$ supplementation or dietary vitamin $\mathrm{D}$ and $\mathrm{KC}$ incidence $[56,76]$.

In a genetic study, the presence of the TT genotype in the Fok1 polymorphism of the VDR gene was associated with a greater than tenfold increase in the risk of BCC (OR: 10.14, $\mathrm{p}<0.001)$. Other VDR polymorphisms were also associated with increased BCC risk, but not so strongly [82]. The Fok1 polymorphism corresponds to a C/T substitution in exon 4 leading to a new translation initiation site and a longer VDR protein that is less transcriptionally active. In an Australian study, homozygous genotypes of the Taq1 polymorphism, TT/tt, were associated with an increased risk of developing solar keratosis, compared with VDR heterodimers, for example, $\mathrm{Tt}$ [85]. One study showed that the expression of the VDR was significantly higher in BCCs of the patients than in the healthy skin of the controls [82].

Vitamin D \& prognosis after skin cancer diagnosis

Cultured melanoma cells express the 25 -hydroxylase enzyme that converts $25(\mathrm{OH})$ $\mathrm{D}$ to $1,25(\mathrm{OH})_{2} \mathrm{D}[86]$. However, recent evidence 
suggests that many melanoma cell lines are resistant to the antiproliferative effects of $1,25(\mathrm{OH}) \mathrm{D}$ [66]. In one study using immunosuppressed mice with human solid xenograft melanoma lines, administration of pharmacological doses of $1,25(\mathrm{OH})_{2} \mathrm{D}$ suppressed the growth of the CMM and inhibited metastasis in one line but not another [87]. Reduction in expression of the VDR [88] and CYP27B1 [89] within CMM is correlated with more aggressive and advanced tumors and lower survival, suggesting that $1,25(\mathrm{OH}) \mathrm{D}$ may play a role in prognosis.

Results from human studies are generally relatively consistent in showing that low $25(\mathrm{OH}) \mathrm{D}$ levels are associated with thicker CMM, later stage or worse prognosis (summarized in Table 1). However, in all of the studies published to date vitamin D status was measured several months after diagnosis, so reverse causality - more aggressive CMM causing greater ill health and resulting in lower sun exposure and therefore vitamin $\mathrm{D}$ production - cannot be ruled out (see Table 1).

It is important to note that there is no evidence that vitamin $\mathrm{D}$ supplementation postdiagnosis improves prognosis, and Hutchinson and colleagues suggest it may even have adverse effects, for example through immune suppression [94].

Vitamin D or an independent effect of sun exposure?

Several of the studies cited above show that the ranking of serum $25(\mathrm{OH}) \mathrm{D}$ levels remains stable over several years and is highly correlated with recent sun exposure - individuals with higher exposure to the sun have higher $25(\mathrm{OH}) \mathrm{D}$ levels and vice versa. In recent years, there has been considerable interest in possible independent effects of sun exposure on health, particularly immune-mediated effects that are not occurring through a vitamin D pathway [95]. Here we consider this issue in relation to skin cancer development and prognosis.

One of the first studies to raise a question about a possible beneficial effect of sun exposure on melanoma prognosis, was that of Berwick and colleagues, who reported that higher (compared with lower) self-reported intermittent lifetime sun exposure was associated with a lower risk of death from CMM within 5 years of diagnosis (HR: 0.6; 95\% CI: 0.3-1.0; p = 0.04) [96]. Serum 25(OH)D levels were not measured. In their more recent study, however, these findings were not replicated, and sun exposure prior to diagnosis was not associated with survival after melanoma diagnosis [97]. A study of European patients with CMM found that those who reported more sunny vacations prior to diagnosis had better survival [98]. The assumed pathway has been through the protective effects of higher vitamin $\mathrm{D}$ status but vitamin $\mathrm{D}$ intake has not been shown to alter CMM risk or prognosis. Notably, in many locations, the higher $25(\mathrm{OH}) \mathrm{D}$ levels in those with markers of better prognosis are likely to primarily reflect recent sun exposure rather than vitamin D intake, given that dietary intake and use of supplements is generally low. While the findings from genetic

Table 1. Studies showing a link between 25(OH)D level and markers of melanoma prognosis.

\begin{tabular}{|c|c|c|c|c|}
\hline Study (year) & Measure of prognosis & Sampling of $25(\mathrm{OH}) \mathrm{D}$ & Outcome & Ref. \\
\hline $\begin{array}{l}\text { Randerson- } \\
\text { Moor et al. } \\
\text { (2009) }\end{array}$ & Breslow thickness & $\begin{array}{l}\text { At least } 3-6 \text { months after } \\
\text { diagnosis }\end{array}$ & $\begin{array}{l}\text { Inverse correlation } \\
\text { between } 25(\mathrm{OH}) \mathrm{D} \text { level } \\
\text { and Breslow thickness }\end{array}$ & [90] \\
\hline $\begin{array}{l}\text { Gambichler } \\
\text { et al. (2013) }\end{array}$ & Breslow thickness & $\begin{array}{l}\text { At baseline (up to } \\
6 \text { months after diagnosis) } \\
\text { and } 6 \text { months later }\end{array}$ & $\begin{array}{l}\text { Lower Breslow thickness } \\
\text { was a predictor of high } \\
25(\mathrm{OH}) \mathrm{D} \text { concentration }\end{array}$ & [91] \\
\hline $\begin{array}{l}\text { Nurnberg et al. } \\
\text { (2009) }\end{array}$ & $\begin{array}{l}\text { CMM stage at } \\
\text { diagnosis }\end{array}$ & $\begin{array}{l}\text { Sampling between } \\
\text { October and April (time } \\
\text { between diagnosis and } \\
\text { sampling highly variable) }\end{array}$ & $\begin{array}{l}\text { Serum } 25(\mathrm{OH}) \text { D levels } \\
\text { significantly lower in } \\
\text { stage IV vs stage } 1 \mathrm{CMM}\end{array}$ & [92] \\
\hline $\begin{array}{l}\text { Newton-Bishop } \\
\text { et al. } 2009\end{array}$ & $\begin{array}{l}\text { Breslow thickness; } \\
\text { relapse-free survival }\end{array}$ & $\begin{array}{l}\text { Sampling 3-6 months } \\
\text { after diagnosis }\end{array}$ & $\begin{array}{l}\text { Significant trend toward } \\
\text { lower } 25(\mathrm{OH}) \mathrm{D} \text { levels in } \\
\text { association with higher } \\
\text { Breslow thickness and } \\
\text { lower relapse-free } \\
\text { survival }\end{array}$ & [93] \\
\hline
\end{tabular}


studies (reviewed above) do suggest that vitamin $\mathrm{D}$ is important, an additional independent effect of sun exposure cannot be ruled out.

\section{What do I tell my skin cancer patients?}

There remains considerable controversy around the optimal level of $25(\mathrm{OH}) \mathrm{D}$ that is necessary for good health. Some suggest the optimal serum level of $25(\mathrm{OH}) \mathrm{D}$ should reflect the concentration necessary to suppress the parathyroid hormone, but this level has been reported to vary widely from 20 nanomoles per litre (nmol/l) to $110 \mathrm{nmol} / \mathrm{l}$ [99-101]. Many observational studies link low $25(\mathrm{OH}) \mathrm{D}$ levels with increased risk of a range of internal cancers [102]. However, based on a review of associations with a wide range of disease outcomes, the United States Institute of Medicine recommended that there was sufficient evidence of a causal association only in relation to requirements for bone health, and recommended that a serum $25(\mathrm{OH}) \mathrm{D}$ level of $50 \mathrm{nmol} / \mathrm{l}$ should be considered sufficient [103]. Further, while there was a general consensus that less than $25 \mathrm{nmol} / \mathrm{l}$ was classed as deficiency $[104,105]$, the Institute of Medicine concluded that less than $30 \mathrm{nmol} / \mathrm{l}$ constituted risk of deficiency [103]. A further challenge lies in the wide variability in measurement results dependent on the assays and laboratory techniques used [106-108].

There is considerable evidence to suggest that, following a diagnosis of skin cancer, sun exposure and vitamin D status fall (e.g., Idorn $e t a l$. [109]). As a diagnosis of skin cancer increases risk of subsequent skin cancers, it may be appropriate to recommend that people with a history of skin cancer avoid the sun as much as possible and ensure adequate vitamin D status through supplementation. This would apply especially to people who have had multiple skin cancers or who have undergone organ transplants and are at particularly high risk of KC. For people with a first skin cancer diagnosis it may be possible to minimize risk of subsequent skin cancers and maintain vitamin $\mathrm{D}$ without supplementation, but finding the balance is currently difficult for several reasons.

Firstly, calculating the time required in the sun to deliver a given dose of vitamin $\mathrm{D}$ relies on the existence of an accurate action spectrum. The International Commission on Illumination (CIE) has published an action spectrum for the production of previtamin $\mathrm{D}$ [110] but recent work suggests that it may not be accurate [111]. In addition, models generated to estimate the dose-response between UV irradiation and change in $25(\mathrm{OH}) \mathrm{D}$ levels have used nonsolar simulated irradiation sources, or have included only very small numbers of participants of a narrow age range or skin type. At this stage there is insufficient evidence on the dose-response for individuals of different age and skin type, to make recommendations on the optimal time in the sun.

Vitamin D production is induced only by UV-B radiation and thus occurs most efficiently when the UV-B intensity is highest [39]. UV-B intensity is well reflected by the UV Index (UVI) $[112,113]$. The differences between the CIE previtamin $\mathrm{D}$ action spectrum and the CIE action spectrum for erythema mean that, to maximize vitamin $\mathrm{D}$ production while minimizing the risk of erythema, it is best to seek sun exposure when the UVI is high (e.g., at noon), rather than low as is currently recommended.

The greater the skin surface area that is exposed to the sun, the greater the production of vitamin $\mathrm{D}_{3}[41]$. On the contrary, for erythema it is the dose to any piece of skin or epidermal cell that causes DNA damage and increases risk of skin cancer. Thus, the message for optimal vitamin D production would be to expose as much skin as possible for a short time when the UVI is high. The risk in implementing such a message is that, despite the ratio between vitamin $\mathrm{D}_{3}$ production and erythema being optimal at high UVI, the absolute difference in the time required to achieve the two outcomes is small. As an example, based on current dose-response models and CIE action spectra, when the UVI index is 12 it takes less than 5 min to make an acceptable daily dose of vitamin $\mathrm{D}$ with the face and arms exposed, but only about $15 \mathrm{~min}$ for somebody with type 2 skin to experience erythema [112]. While extreme caution would be required to avoid harmful levels of sun exposure, the appropriate strategy for people at high risk of skin cancer may be to routinely apply sunscreen to the hands, face and arms [114], but to deliberately expose less frequently exposed areas of skin for a short time at a high UVI.

\section{Conclusion}

It is difficult, on the evidence to date, to provide any definitive answers on whether vitamin $\mathrm{D}$ has any protective role in skin cancer development or prognosis. Higher 25(OH)D levels postdiagnosis and higher sun exposure prediagnosis have been associated with thinner CMM 
and better prognosis, but it is impossible to tell how indicative the postdiagnostic $25(\mathrm{OH}) \mathrm{D}$ levels are of the prediagnostic situation. On the other hand, there is clear evidence that sun exposure increases the risk of all types of skin cancers. On the basis of the evidence reviewed here, it is prudent to avoid high dose sun exposure leading to sunburn, to always protect the face and hands when in the sun, and to use sun protection when outdoors for other than short periods of time when the UVI is 3 or higher. It is important to maintain $25(\mathrm{OH}) \mathrm{D}$ levels of around $50 \mathrm{nmol} / \mathrm{l}$ or higher, and in many locations this should be achievable with short periods of sun exposure during the middle of the day in most seasons, with additional intake of vitamin $\mathrm{D}$ possibly required in winter in some locations.

\section{Future perspective}

Ideally, the question of the role of vitamin $\mathrm{D}$ in skin cancer would be resolved by clinical trials of vitamin D supplementation at appropriate levels for a sufficient duration. Such trials are unlikely to ever be possible for CMM because it is uncommon, although a large enough study, undertaken in a high risk group (e.g., living in a high ambient UVR location), may provide evidence to support or refute a role of vitamin D. Current trials underway in elderly people, primarily looking at other end points such as all-cause mortality, may generate enough $\mathrm{KC}$ outcomes for this end point also to be examined.

Financial \& competing interests disclosure The authors have no relevant affiliations or financial involvement with any organization or entity with a financial interest in or financial conflict with the subject matter or materials discussed in the manuscript. This includes employment, consultancies, honoraria, stock ownership or options, expert testimony, grants or patents received or pending, or royalties.

No writing assistance was utilized in the production of this manuscript.

\section{References}

Papers of special note have been highlighted as: - of interest; $\bullet$ of considerable interest

1 IARC. Globocan 2012. Estimated cancer incidence, mortality and prevalence worldwide in 2012 (2014).

http://globocan.iarc.fr

2 Erdmann F, Lortet-Tieulent J, Schuz J et al. International trends in the incidence of malignant melanoma 1953-2008-are recent generations at higher or lower risk? Int. J. Cancer 132(2), 385-400 (2013).

3 Czarnecki $\mathrm{D}$. The incidence of melanoma is increasing in the susceptible young Australian population. Acta. Derm. Venereol. 94(5), 539-541 (2014).

4 Cakir BO, Adamson P, Cingi C. Epidemiology and economic burden of nonmelanoma skin cancer. Facial Plast. Surg. Clin. North Am. 20 (4), 419-422 (2012).

5 Xiang F, Lucas R, Hales S, Neale RE. Incidence of keratinocyte cancer in relation to ambient ultraviolet radiation in white populations (1978-2012): empirical relationships. JAMA Dermatol. (2014) (In press).

6 Whiteman DC, Green AC. A risk prediction tool for melanoma? Cancer Epidemiol. Biomarkers Prev. 14(4), 761-763 (2005).

7 Curado M, Edwards B, Shin $\mathrm{H}$ et al. Cancer Incidence in Five Continents, Vol. IX. IARC Scientific Publications No. 160 (2007).
8 Boniol M, De Vries E, Coebergh JW, Dore JF. Seasonal variation in the occurrence of cutaneous melanoma in Europe: influence of latitude. An analysis using the EUROCARE group of registries. Eur. J. Cancer 41(1), 126-132 (2005).

9 Armstrong BK, Kricker A, English DR. Sun exposure and skin cancer. Austral. J. Derm. 38(Suppl. 1), S1-S6 (1997).

10 Whiteman DC, Green A. Melanoma and sun exposure: where are we now? Int. J. Dermatol. 38(7), 481-489 (1999).

11 Australian Institute of Health and Welfare. Cancer in Australia: an overview, 2008. Cancer Series no. 46. www.aihw.gov.au

12 De Vries E, Coebergh JW. Cutaneous malignant melanoma in Europe. Eur. J. Cancer 40 (16), 2355-2366 (2004).

13 Diffey B. A behavioral model for estimating population exposure to solar ultraviolet radiation. Photochem. Photobiol. 84(2), 371-375 (2008).

14 Birch-Johansen F, Hvilsom G, Kjaer T, Storm H. Social inequality and incidence of and survival from malignant melanoma in a population-based study in Denmark, 1994-2003. Eur. J. Cancer 44(14), 2043-2049 (2008).

15 Lomas A, Leonardi-Bee J, Bath-Hextall F. A systematic review of worldwide incidence of nonmelanoma skin cancer. $B r$.
J. Dermatol. 166(5), 1069-1080 (2012).

16 Balch CM, Soong S-J, Gershenwald JE et al. Prognostic factors analysis of 17,600 melanoma patients: validation of the American Joint Committee on Cancer Melanoma Staging System. J. Clin. Oncol. 19(16), 3622-3634 (2001).

17 McGovern VJ. Melanoblastoma. Med. J. Aust. 1(5), 139-142 (1952).

18 Armstrong B, Kricker A. How much melanoma is caused by sun exposure? Melanoma Res. 3(6), 395-401 (1993).

19 Gloster HM Jr, Neal K. Skin cancer in skin of color. J. Am. Acad. Dermatol. 55(5), 741-760; quiz 761-744 (2006).

20 Gandini S, Sera F, Cattaruzza MS et al. Meta-analysis of risk factors for cutaneous melanoma: III. Family history, actinic damage and phenotypic factors. Eur. J. Cancer 41(14), 2040-2059 (2005).

21 Gandini S, Sera F, Cattaruzza MS et al. Meta-analysis of risk factors for cutaneous melanoma: II. Sun exposure. Eur. J. Cancer 41(1), 45-60 (2005).

22 Gandini S, Sera F, Cattaruzza MS et al. Meta-analysis of risk factors for cutaneous melanoma: I. Common and atypical naevi. Eur. J. Cancer 41(1), 28-44 (2005).

23 Rees JR, Zens MS, Gui J, Celaya MO, Riddle BL, Karagas MR. Non melanoma 
skin cancer and subsequent cancer risk. PLoS ONE 9(6), e99674 (2014).

24 Hill VK, Gartner JJ, Samuels Y, Goldstein AM. The genetics of melanoma: recent advances. Annu. Rev. Genomics Hum. Genet. 14, 257-279 (2013).

25 Hodis E, Watson IR, Kryukov GV et al. A landscape of driver mutations in melanoma. Cell 150(2), 251-263 (2012).

- Describes the large number of mutations in melanoma, including UV-signature driver mutations as well as passenger mutations.

26 Brash DE, Ziegler A, Jonason AS, Simon JA, Kunala S, Leffell DJ. Sunlight and sunburn in human skin cancer: p53, apoptosis, and tumor promotion. J. Investig. Dermatol. Symp. Proc. 1(2), 136-142 (1996).

27 Ziegler A, Jonason AS, Leffell DJ et al. Sunburn and $\mathrm{p} 53$ in the onset of skin cancer. Nature 372(6508), 773-776 (1994).

28 Jayaraman SS, Rayhan DJ, Hazany S, Kolodney MS. Mutational landscape of basal cell carcinomas by whole-exome sequencing. J. Invest. Dermatol. 134(1), 213-220 (2014).

- A recent paper describing the high number of mutations in basal cell carcinomas and the prominence of signature UV lesions.

29 Berger MF, Hodis E, Heffernan TP et al. Melanoma genome sequencing reveals frequent PREX2 mutations. Nature 485(7399), 502-506 (2012).

30 Durinck S, Ho C, Wang NJ et al. Temporal dissection of tumorigenesis in primary cancers. Cancer Discov. 1(2), 137-143 (2011).

31 Krauthammer M, Kong Y, Ha BH et al. Exome sequencing identifies recurrent somatic RAC1 mutations in melanoma. Nat. Genet. 44(9), 1006-1014 (2012).

32 Khalesi M, Whiteman DC, Doi SA, Clark J, Kimlin MG, Neale RE. Cutaneous markers of photo-damage and risk of Basal cell carcinoma of the skin: a meta-analysis. Cancer Epidemiol. Biomarkers Prev. 22(9), 1483-1489 (2013).

33 Armstrong BK, Kricker A. The epidemiology of UV induced skin cancer. J. Photochem. Photobiol. B Biol. 63(1-3), 8-18 (2001).

34 Autier P, Dore JF. Influence of sun exposures during childhood and during adulthood on melanoma risk. EPIMEL and EORTC Melanoma Cooperative Group. European Organisation for Research and Treatment of Cancer. Int. J. Cancer 77(4), 533-537 (1998).

35 Leiter U, Garbe C. Epidemiology of melanoma and nonmelanoma skin cancer the role of sunlight. Adv. Exp. Med. Biol. 624, 89-103 (2008).
36 Whiteman DC, Watt P, Purdie DM, Hughes MC, Hayward NK, Green AC. Melanocytic nevi, solar keratoses, and divergent pathways to cutaneous melanoma. J. Natl Cancer Inst. 95(11), 806-812 (2003).

37 Neale RE, Davis M, Pandeya N, Whiteman DC, Green AC. Basal cell carcinoma on the trunk is associated with excessive sun exposure. J. Am. Acad. Dermatol. 56(3), 380-386 (2007).

38 Bikle DD. Vitamin D metabolism and function in the skin. Mol. Cell Endocrinol. 347(1-2), 80-89 (2011).

39 Engelsen O. The relationship between ultraviolet radiation exposure and vitamin $\mathrm{D}$ status. Nutrients 2(5), 482-495 (2010).

40 Bogh MK, Schmedes AV, Philipsen PA, Thieden E, Wulf HC. Vitamin D production after UVB exposure depends on baseline vitamin $\mathrm{D}$ and total cholesterol but not on skin pigmentation. J. Invest. Dermatol. 130 (2), 546-553 (2010).

41 Bogh MK, Schmedes AV, Philipsen PA, Thieden E, Wulf HC. Vitamin D production depends on ultraviolet-B dose but not on dose rate: a randomized controlled trial. Exp. Dermatol. 20(1), 14-18 (2011).

42 Farrar MD, Webb AR, Kift R et al. Efficacy of a dose range of simulated sunlight exposures in raising vitamin D status in South Asian adults: implications for targeted guidance on sun exposure. Am. J. Clin. Nutr. 97(6), 1210-1216 (2013).

43 Bogh MK, Schmedes AV, Philipsen PA, Thieden E, Wulf HC. Interdependence between body surface area and ultraviolet B dose in vitamin $D$ production: a randomized controlled trial. Br. J. Dermatol. 164(1), 163-169 (2011).

44 Matsuoka LY, Wortsman J, Hanifan N, Holick MF. Chronic sunscreen use decreases circulating concentrations of 25-hydroxyvitamin D. A preliminary study. Arch. Dermatol. 124(12), 1802-1804 (1988).

45 Lucas RM, Ponsonby AL, Dear K et al. Vitamin D status: multifactorial contribution of environment, genes and other factors in healthy Australian adults across a latitude gradient. J. Steroid Biochem. Mol. Biol. 136, 300-308 (2013).

46 Nair-Shalliker V, Clements M, Fenech M, Armstrong BK. Personal sun exposure and serum 25-hydroxyvitamin D concentrations. Photochem. Photobiol. 89(1), 208-214 (2012).

47 Vu LH, Whiteman DC, Van Der Pols JC, Kimlin MG, Neale RE. Serum vitamin D levels in office workers in a subtropical climate. Photochem. Photobiol. 87(3), 714-720 (2011).
48 Matsuoka LY, Wortsman J, Haddad JG, Hollis BW. Skin types and epidermal photosynthesis of vitamin D3. J. Am. Acad. Dermatol. 23(3 Pt 1), 525-526 (1990).

49 Matsuoka LY, Wortsman J, Haddad JG, Kolm P, Hollis BW. Racial pigmentation and the cutaneous synthesis of vitamin D. Arch. Dermatol. 127(4), 536-538 (1991).

50 Armas LA, Dowell S, Akhter M et al. Ultraviolet-B radiation increases serum 25-hydroxyvitamin D levels: the effect of UVB dose and skin color. J. Am. Acad. Dermatol. 57(4), 588-593 (2007).

51 Clemens TL, Adams JS, Henderson SL, Holick MF. Increased skin pigment reduces the capacity of skin to synthesise vitamin D3. Lancet 1(8263), 74-76 (1982).

52 Farrar MD, Kift R, Felton SJ et al. Recommended summer sunlight exposure amounts fail to produce sufficient vitamin D status in UK adults of South Asian origin. Am. J. Clin. Nutr. 94(5), 1219-1224 (2011).

53 Libon F, Cavalier E, Nikkels AF. Skin color is relevant to vitamin $\mathrm{D}$ synthesis. Dermatology 227(3), 250-254 (2013).

54 Norman AW, Mizwicki MT, Norman DP. Steroid-hormone rapid actions, membrane receptors and a conformational ensemble model. Nat. Rev. Drug Discov. 3(1), 27-41 (2004).

55 Bikle DD. Vitamin D: an ancient hormone. Exp. Dermatol. 20(1), 7-13 (2011).

56 Autier P, Boniol M, Pizot C, Mullie P. Vitamin D status and ill health: a systematic review. Lancet Diabetes Endocrinol. 2(1), 76-89 (2014).

57 Theodoratou E, Tzoulaki I, Zgaga L, Ioannidis JPA. Vitamin D and multiple health outcomes: umbrella review of systematic reviews and meta-analyses of observational studies and randomised trials. Br. Med. J. 348, 2035 (2014).

58 Lehmann B, Tiebel O, Meurer M. Expression of vitamin D3 25-hydroxylase (CYP27) mRNA after induction by vitamin D3 or UVB radiation in keratinocytes of human skin equivalents-a preliminary study. Arch. Dermatol. Res. 291(9), 507-510 (1999).

59 Colston K, Colston MJ, Fieldsteel AH, Feldman D. 1,25-dihydroxyvitamin D3 receptors in human epithelial cancer cell lines. Cancer Res. 42(3), 856-859 (1982).

60 Pillai S, Bikle DD, Elias PM. 1,25-Dihydroxyvitamin D production and receptor binding in human keratinocytes varies with differentiation. J. Biol. Chem. 263(11), 5390-5395 (1988). 
61 Bikle DD. Vitamin D and the skin: physiology and pathophysiology. Rev. Endocr. Metab. Disord. 13(1), 3-19 (2012).

62 Colston K, Colston MJ, Feldman D. 1,25-dihydroxyvitamin D3 and malignant melanoma: the presence of receptors and inhibition of cell growth in culture. Endocrinology 108(3), 1083-1086 (1981).

63 De Haes P, Garmyn M, Degreef H, Vantieghem K, Bouillon R, Segaert S. 1,25-Dihydroxyvitamin D3 inhibits ultraviolet B-induced apoptosis, Jun kinase activation, and interleukin-6 production in primary human keratinocytes. J. Cell Biochem. 89(4), 663-673 (2003).

64 Dixon KM, Norman AW, Sequeira VB et al. 1alpha, 25( $\mathrm{OH})(2)$-vitamin $\mathrm{D}$ and a nongenomic vitamin $\mathrm{D}$ analogue inhibit ultraviolet radiation-induced skin carcinogenesis. Cancer Prev. Res. (Phila.) 4(9), 1485-1494 (2011).

65 Diesel B, Seifert M, Radermacher J et al. Towards a complete picture of splice variants of the gene for 25-hydroxyvitamin D31alphahydroxylase in brain and skin cancer. J. Steroid Biochem. Mol. Biol. 89-90(1-5), 527-532 (2004).

66 Reichrath J, Rech M, Moeini M, Meese E, Tilgen W, Seifert M. In vitro comparison of the vitamin D endocrine system in 1,25(OH)2D3responsive and -resistant melanoma cells. Cancer Biol. Ther. 6(1), 48-55 (2007).

67 Essa S, Denzer N, Mahlknecht U et al. VDR microRNA expression and epigenetic silencing of vitamin D signaling in melanoma cells. J. Steroid Biochem. Mol. Biol. 121(1-2), 110-113 (2010).

68 Shannan B, Seifert M, Leskov K et al. Clusterin (CLU) and melanoma growth: CLU is expressed in malignant melanoma and 1,25-dihydroxyvitamin D3 modulates expression of CLU in melanoma cell lines in vitro. Anticancer Res. 26(4A), 2707-2716 (2006).

69 Dowd DR, Macdonald PN. The 1,25-dihydroxyvitamin D3-independent actions of the vitamin D receptor in skin. J. Steroid Biochem. Mol. Biol. 121(1-2), 317-321 (2010).

70 Teichert AE, Elalieh H, Elias PM, Welsh J, Bikle DD. Overexpression of hedgehog signaling is associated with epidermal tumor formation in vitamin D receptor-null mice. J. Invest. Dermatol. 131(11), 2289-2297 (2011).

71 Jiang YJ, Bikle DD. LncRNA: a new player in 1alpha, 25(OH)(2) vitamin D(3)/VDR protection against skin cancer formation. Exp. Dermatol. 23(3), 147-150 (2014).
72 Bikle DD. The vitamin D receptor: a tumor suppressor in skin. Discov. Med. 11(56), 7-17 (2011).

73 Major JM, Kiruthu C, Weinstein SJ et al. Pre-diagnostic circulating vitamin $\mathrm{d}$ and risk of melanoma in men. PLoS ONE 7(4), e35112 (2012).

74 Afzal S, Nordestgaard BG, Bojesen SE. Plasma 25-hydroxyvitamin $\mathrm{D}$ and risk of nonmelanoma and melanoma skin cancer: a prospective cohort study. J. Invest. Dermatol. 133(3), 629-636 (2013).

75 Van Der Pols JC, Russell A, Bauer U, Neale RE, Kimlin MG, Green AC. Vitamin D status and skin cancer risk independent of time outdoors: 11-year prospective study in an Australian community. J. Invest. Dermatol. 133(3), 637-641 (2013).

76 Caini S, Boniol M, Tosti G et al. Vitamin D and melanoma and non-melanoma skin cancer risk and prognosis: a comprehensive review and meta-analysis. Eur. J. Cancer 50 (15), 2649-2658 (2014).

- A recent meta-analysis of the field showing no evidence that vitamin $\mathrm{D}$ deficiency increases the risk of melanoma, but suggestive evidence that vitamin $\mathrm{D}$ deficiency may be associated with thicker melanomas at diagnosis and worse prognosis.

77 Tang JY, Fu T, Leblanc E et al. Calcium plus vitamin $\mathrm{D}$ supplementation and the risk of nonmelanoma and melanoma skin cancer: post hoc analyses of the Women's Health Initiative randomized controlled trial. J. Clin. Oncol. 29(22), 3078-3084 (2011).

78 Gandini S, Raimondi S, Gnagnarella P, Dore JF, Maisonneuve P, Testori A. Vitamin D and skin cancer: a meta-analysis. Eur. J. Cancer 45(4), 634-641 (2009).

79 Randerson-Moor JA, Taylor JC, Elliott F et al. Vitamin D receptor gene polymorphisms, serum 25-hydroxyvitamin D levels, and melanoma: UK case-control comparisons and a meta-analysis of published VDR data. Eur. J. Cancer 45(18), 3271-3281 (2009).

80 Schafer A, Emmert S, Kruppa J et al. No association of vitamin D metabolism-related polymorphisms and melanoma risk as well as melanoma prognosis: a case-control study. Arch. Dermatol. Res. 304(5), 353-361 (2012).

81 Tang JY, Parimi N, Wu A et al. Inverse association between serum $25(\mathrm{OH})$ vitamin D levels and non-melanoma skin cancer in elderly men. Cancer Causes Control 21(3), 387-391 (2010).

82 Lesiak A, Norval M, Wodz-Naskiewicz K et al. An enhanced risk of basal cell carcinoma is associated with particular polymorphisms in the VDR and MTHFR genes. Exp.

Dermatol. 20(10), 800-804 (2011).

83 Liang G, Nan H, Qureshi AA, Han J. Pre-diagnostic plasma 25-hydroxyvitamin D levels and risk of non-melanoma skin cancer in women. PLoS ONE 7(4), e35211 (2012).

84 Asgari MM, Tang J, Warton ME et al. Association of prediagnostic serum vitamin $D$ levels with the development of basal cell carcinoma. J. Invest. Dermatol. 130(5), 1438-1443 (2010).

85 Carless MA, Kraska T, Lintell N, Neale RE, Green AC, Griffiths LR. Polymorphisms of the VDR gene are associated with presence of solar keratoses on the skin. $\mathrm{Br}$. J. Dermatol. 159(4), 804-810 (2008).

86 Seifert M, Rech M, Meineke V, Tilgen W, Reichrath J. Differential biological effects of 1,25-dihydroxyvitamin $\mathrm{D}_{3}$ on melanoma cell lines in vitro. J. Steroid Biochem. Mol. Biol. 89-90 (1-5), 375-379 (2004).

87 Eisman J, Barkla D, Tutton P. Suppression of in vivo growth of human cancer solid tumor xenographs by

1,25-dihydroxyvitamin $\mathrm{D}_{3}$. Cancer Res. 47, 21-25 (1987).

88 Brozyna AA, Jozwicki W, Janjetovic Z, Slominski AT. Expression of vitamin D receptor decreases during progression of pigmented skin lesions. Hum. Pathol. 42(5), 618-631 (2011).

89 Brozyna AA, Jozwicki W, Janjetovic Z, Slominski AT. Expression of the vitamin D-activating enzyme lalpha-hydroxylase (CYP27B1) decreases during melanoma progression. Hum. Pathol. 44(3), 374-387 (2013).

90 Randerson-Moor JA, Taylor JC, Elliott F et al. Vitamin D receptor gene polymorphisms, serum 25-hydroxyvitamin D levels, and melanoma: UK case-control comparisons and a meta-analysis of published VDR data. Eur. J. Cancer 45(18), 3271-3281 (2009).

91 Gambichler T, Bindsteiner M, Hoxtermann S, Kreuter A. Serum 25-hydroxyvitamin D serum levels in a large German cohort of patients with melanoma. Br. J. Dermatol. 168(3), 625-628 (2013).

92 Nurnberg B, Graber S, Gartner B et al. Reduced serum 25-hydroxyvitamin D levels in stage IV melanoma patients. Anticancer Res. 29(9), 3669-3674 (2009).

93 Newton-Bishop JA, Beswick S, RandersonMoor J et al. Serum 25-hydroxyvitamin D3 levels are associated with breslow thickness at presentation and survival from melanoma. J. Clin. Oncol. 27, 5439-5444 (2009). 
94 Hutchinson PE, Osborne JE, Pringle JH. Higher serum 25-hydroxy vitamin D3 levels at presentation are associated with improved survival from melanoma, but there is no evidence that later prevailing levels are protective. J. Clin. Oncol. 28(27), e492-e493; author reply 494-495 (2010).

95 Hart PH, Gorman S, Finlay-Jones JJ. Modulation of the immune system by UV radiation: more than just the effects of vitamin D? Nat. Rev. Immunol. 11(9), 584-596 (2011).

- A seminal paper examining non-vitamin D pathways to UV-induced immune suppression.

96 Berwick M, Armstrong BK, Ben-Porat L et al. Sun exposure and mortality from melanoma. J. Natl Cancer Inst. 97(3), 195-199 (2005).

97 Berwick M, Reiner AS, Paine S et al. GEM Study Group. Sun exposure and melanoma survival: a GEM study. Cancer Epidemiol. Biomarkers Prev. 23(10), 2145-2152 (2014).

98 Rosso S, Sera F, Segnan N, Zanetti R. Sun exposure prior to diagnosis is associated with improved survival in melanoma patients: results from a long-term follow-up study of Italian patients. Eur. J. Cancer 44(9), 1275-1281 (2008).

99 Dawson-Hughes B, Heaney RP, Holick MF, Lips P, Meunier PJ, Vieth R. Estimates of optimal vitamin D status. Osteoporos. Int. 16(7), 713-716 (2005).

100 Lips P. Which circulating level of 25 -hydroxyvitamin $\mathrm{D}$ is appropriate? J. Steroid. Biochem. Mol. Biol. 89-90(1-5), 611-614 (2004).

101 Vieth R. What is the optimal vitamin D status for health? Prog. Biophys. Mol.
Biol. 92(1), 26-32 (2006).

102 Peterlik M. Vitamin D insufficiency and chronic diseases: hype and reality. Food Funct. 3(8), 784-794 (2012).

103 Institute of Medicine (IOM). Dietary reference intakes for calcium and vitamin $\mathrm{D}$ (2011). www.iom.edu

104 Johnson MA, Kimlin MG. Vitamin D, aging, and the 2005 dietary guidelines for Americans. Nutr. Rev. 64(9), 410-421 (2006).

105 Bischoff-Ferrari HA, Giovannucci E, Willett WC, Dietrich T, Dawson-Hughes B. Estimation of optimal serum concentrations of 25-hydroxyvitamin D for multiple health outcomes. Am. J. Clin. Nutr. 84(1), 18-28 (2006).

106 Holick MF. Vitamin D status: measurement, interpretation, and clinical application. Ann. Epidemiol. 19(2), 73-78 (2009).

107 Binkley N, Krueger D, Lensmeyer G. 25-hydroxyvitamin D measurement, 2009: a review for clinicians. J. Clin. Densitom. 12(4), 417-427 (2009).

108 Lai JK, Lucas RM, Banks E, Ponsonby AL. Variability in vitamin D assays impairs clinical assessment of vitamin D status. Intern. Med. J. 42(1), 43-50 (2012).

- This paper highlights the wide variability in results from different vitamin $\mathrm{D}$ assays, or the same assay used in different laboratories, as well as the implications of inaccurate and imprecise assays for clinical decision-making.

109 Idorn LW, Philipsen PA, Wulf HC. Sun exposure before and after a diagnosis of cutaneous malignant melanoma: estimated by developments in serum vitamin $\mathrm{D}$, skin pigmentation and interviews. $\mathrm{Br}$. J. Dermatol. 165(1), 164-170 (2011).

110 Commission Internationale De L'eclairage. CIE 174:2006 Action Spectrum for the Production of Previtamin D3 in Human Skin (2006). http://div6.cie.co.at

111 Norval M, Bjorn LO, De Gruijl FR. Is the action spectrum for the UV-induced production of previtamin D3 in human skin correct? Photochem. Photobiol. Sci. 9(1), 11-17 (2010).

- Presents evidence that questions the accuracy of the current International Commission on Illumination action spectrum for the synthesis of previtamin $\mathrm{D}_{3}$ in human skin, and some of the implications for estimates of vitamin D production.

112 McKenzie RL, Liley JB, Bjorn LO. UV radiation: balancing risks and benefits. Photochem. Photobiol. 85(1), 88-98 (2009).

113 McKenzie R, Scragg R, Liley B et al. Serum 25-hydroxyvitamin-D responses to multiple UV exposures from solaria: inferences for exposure to sunlight. Photochem. Photobiol. Sci. 11(7), 1174-1185 (2012).

114 Green A, Williams G, Neale R et al. Daily sunscreen application and betacarotene supplementation in prevention of basal-cell and squamous-cell carcinomas of the skin: a randomised controlled trial. Lancet 354(9180), 723-729 (1999). 